\title{
Ekonomia współdzielenia w opinii urzędników i przedsiębiorców województwa świętokrzyskiego - wnioski z badań empirycznych ${ }^{1}$
}

\author{
Marcin Banaszek* \\ Streszczenie: Ekonomia współdzielenia jest zjawiskiem społeczno-ekonomicznym polegającym na bezpośred- \\ nim świadczeniu usług przez ludzi, współtworzeniu oraz współużytkowaniu dostępnych zasobów. \\ Jej głównym celem jest przejście z własności na dostęp. Celem artykułu jest przedstawienie eko- \\ nomii współdzielenia w kontekście miejskiej problematyki w świadomości urzędników i przedsię- \\ biorców województwa świętokrzyskiego. W badaniach, które miały charakter zarówno jakościowy, \\ jak i ilościowy, zastosowano metodę sondażu diagnostycznego i dwie techniki badawcze: tech- \\ nikę wywiadu pogłębionego i technikę ankiety. Narzędziami, jakimi posłużono się w celu przepro- \\ wadzenia badań, były kwestionariusz wywiadu i kwestionariusz ankiety. Ekonomia współdzielenia \\ jest zjawiskiem relatywnie słabo rozwiniętym w województwie świętokrzyskim. Zaufanie jest jed- \\ nym z newralgicznych czynników, które umożliwiają funkcjonowanie ekonomii współdzielenia.
}

Słowa kluczowe: ekonomia współdzielenia, ekonomia społeczna, rozwój, miasto, konsumpcjonizm.

\section{Wprowadzenie}

W wyniku rozwoju gospodarki cyfrowej wyłania się stosunkowo nowa forma działalności gospodarczej, zwana ekonomią współdzielenia (ang. sharing economy). Nowy nurt ekonomiczno-społeczny zbudowany wokół współdzielenia zasobów ludzkich i materialnych wywołuje zarówno pozytywne, jak i negatywne reakcje. Część z nich może wynikać z różnorakiego sposobu definiowania oraz interpretowania tego zjawiska. Niewątpliwie jednak ekonomia współdzielenia to przejaw przedsiębiorczości - lepszej, bardziej ekologicznej, zgodnej z ideą zrównoważonego rozwoju. W wielu miastach na świecie ekonomia współdzielenia staje się trendem będącym alternatywnym kierunkiem w myśleniu

Praca naukowa finansowana ze środków budżetowych na naukę w latach 2016-2018, jako projekt badawczy w ramach programu „Diamentowy Grant”. o przyszłości miast, przed którymi stoją liczne wyzwania związane z poprawą jakości życia, czy wzmocnieniem konkurencyjności. Celem artykułu jest przedstawienie ekonomii współdzielenia w kontekście miejskiej problematyki w świadomości urzędników i przedsiębiorców województwa świętokrzyskiego. W badaniach, które miały charakter zarówno jakościowy, jak i ilościowy zastosowano metodę sondażu diagnostycznego i dwie techniki badawcze: technikę wywiadu pogłębionego i technikę ankiety. Narzędziami, jakimi posłużono się w celu przeprowadzenia badań, były kwestionariusz wywiadu i kwestionariusz ankiety.

\footnotetext{
* Marcin Banaszek

Uniwersytet Jana Kochanowskiego w Kielcach e-mail: banaszek.marcin92@gmail.com
} 


\section{Teoretyczne i definicyjne ujęcie ekonomii współdzielenia}

Ekonomia współdzielenia to jedna $\mathrm{z}$ form odpowiedzi na kryzys ekonomiczny, społeczny i ekologiczny, który w większym bądź mniejszym stopniu daje się we znaki od co najmniej dekady. W obliczu nadmienionych kryzysów na znaczeniu zyskała ekonomia społeczna, która odnosi się do wielu sfer życia społecznego, a jej kluczową zasadą jest reinwestowanie zysków na rzecz wspólnoty [Banaszek, 2016, s. 51]. Ekonomia współdzielenia wpisuje się $\mathrm{w}$ obszar ekonomii społecznej i jest formą aktywności opartej na rozwiązaniach peer-to-peer, która polega na otrzymywaniu, udostępnianiu, dzieleniu się dostępem do różnych dóbr i usług za pośrednictwem internetowych platform opartych na społeczności użytkowników [Hamari, Sjoklint, Ukkonen, 2015, s. 1]. Zdaniem G. Petropoulosa ekonomia współdzielenia polega na kojarzeniu ze sobą użytkowników online, którzy wyrażają chęć dzielenia się ze sobą dobrami i usługami. Przy pomocy platform internetowych strona podażowa (posiadająca nadmiar któregoś z zasobów) spotyka się ze stroną popytową [Petropoulos, 2017, s. 1-3]. Według A. Sundararajana ekonomia współdzielenia składa się z trzech elementów: platformy, przedsiębiorców oraz konsumentów. Przedsiębiorcy wraz z konsumentami to tzw. peers. Natomiast platforma internetowa służy do pobierania prowizji, dokonywania wszelkiego rodzaju opłat za dobra i usługi, a także jest miejscem budowania reputacji społeczności internetowej [Sundararajan, 2014, s. 45]. Katalizatorem, który przyczynił się do powstania ekonomii współdzielenia, był nieustanny dostęp do Internetu oraz innowacyjna komunikacja [Rifkin, 2016, s. 250]. Rozwój ekonomii współdzielenia jest szansą i wyzwaniem, które już teraz przyczynia się do zmiany modeli biznesowych oraz funkcjonowania rynku [Dorda, 2015, s. 30].
Ekonomia współdzielenia jest zjawiskiem nie do końca jeszcze zdefiniowanym. Występuje wiele jej nazw, np.: gospodarka współpracy, wspólna konsumpcja, collaborative economy, peer to peer economy, które używane są zamiennie lub stanowią określony element pojęcia ekonomii współdzielenia, dlatego może pojawiać się problem $z$ jego zrozumieniem. Jednak dyskusja dotycząca nazewnictwa wydaje się być drugorzędną kwestią wobec samej istoty ekonomii współdzielenia.

Ekonomia współdzielenia jest przejawem powszechnej cyfryzacji, która rewolucyjnie zmienia rzeczywistość. Obecnie młode pokolenie wychowywane w czasach wirtualnych wspólnot jest bardziej (niż starsze pokolenia) otwarte na model wspólnotowy. Młode pokolenie stanowi przykład nowego plemienia, które M. Maffesoli charakteryzował przez pryzmat nowych wartości emocjonalnych i intelektualnych [Maffesoli, 2008, s. 86]. Rozwój miast oraz przywracanie utraconych wspólnot lokalnych jest bardzo ważnym zadaniem, dlatego badania naukowe ukierunkowane na problematykę ekonomii współdzielenia wydają się być fundamentalnym aspektem wpisującym się w rozmyślania o ponowoczesnej gospodarce i ponowoczesnym rozwoju miast.

Analizując ekonomię współdzielenia można dostrzec jej różne typologie. R. Botsman [2010] podzieliła sharing economy na trzy główne kategorie (zob. rys. 1). Są to: 1) rynki redystrybucji - ich głównym celem jest przedłużenie cyklu życia produktu oraz ograniczenie ilości odpadów; 2) współdzielony styl życia - polega on na dzieleniu się czasem, umiejętnościami, $n p$. jedna osoba oferuje wyprowadzenie psa na spacer w zamian za naukę języka angielskiego; 3) wynajem dóbr - użytkownicy płacą tylko za czas użytkowania danego dobra, nie muszą posiadać go na własność, dzięki czemu nie ponoszą stałych kosztów związanych $z$ utrzymaniem tego dobra, np. w przypadku użytkowania samochodu, użytkownik płaci tylko za czas jazdy, nie ponosi kosztów zwią- 
zanych z ubezpieczeniem samochodu czy jego

ewentualnymi naprawami.

Rysunek 1. Podział ekonomii współdzielenia według R. Botsman

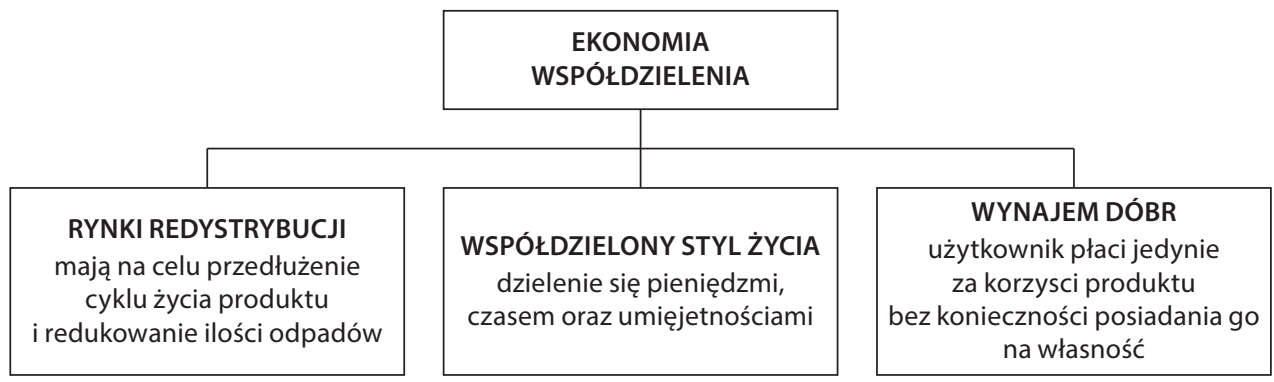

Źródło: opracowanie własne na podstawie: [Botsman, Rogers, 2010].

Można również wyróżnić następujące usługi bazujące na założeniach ekonomii współdzielenia: współużytkowanie samochodów (np. car-sharing, Car2Go, Uber, Zipcar); współużytkowanie rowerów (np. Nextbike, Veturillo); współużytkowanie skuterów elektrycznych (np. Blinkee); wspólne przejazdy prywatnym samochodem między miastami (np. BlaBlaCar); usługi transportowe - przesyłka paczek (np. jadezabiore.pl); udostępnianie mieszkań lub pokoju na wynajem krótkoterminowy (np. Airbnb, HomeAway); edukacja online (np. Codecademy, Skillshare); świadczenie usług przez prywatne osoby (np. TakeTask, SkillHunt); powierzchnie coworkingowe - biura do wspólnej pracy (np. Business Link); współfinansowanie projektów oraz pożyczki od osób prywatnych (np. PolakPotrafi.pl, Trejdoo.com); żywność (np. LokalnyRolnik.pl, RanoZebrane.pl).

W kontekście miejskiej problematyki ekonomia współdzielenia również zyskuje na znaczeniu. Miasta na całym świecie próbują dostosować się do innowacyjnego modelu ekonomicznego, jakim jest wspólna konsumpcja. Skutecznie wykorzystywana ekonomia współdzielenia, o czym świadczą przykłady takich miast jak Seul czy Amsterdam, może być narzędziem polityki miejskiej, która prowadzi nie tylko do ożywienia gospodarki, ale także do zacieśniania relacji w lokalnych wspólnotach [Dorda, 2015, s. 30].

\section{Ekonomia współdzielenia w świetle wyników autorskich badań}

\subsection{Ekonomia współdzielenia w opinii urzędników województwa świętokrzyskiego}

Celem prowadzonych badań była diagnoza obecnego stanu wiedzy urzędników województwa świętokrzyskiego w zakresie ekonomii współdzielenia, uwzględniając kontekst problematyki miejskiej. Badanie przeprowadzono za pomocą kwestionariusza wywiadu na próbie liczącej 14 urzędników Urzędu Marszałkowskiego województwa świętokrzyskiego. Badanie było realizowane w okresie od lipca do września 2017 r.

Grono ekspertów stanowili dyrektorzy lub (w przypadku ich nieobecności) zastępcy dyrektorów departamentów oraz równorzędnych departamentom jednostek organizacyjnych Urzędu Marszałkowskiego województwa świętokrzyskiego. Wśród badanych respondentów było 8 mężczyzn i 6 kobiet. Ich średni wiek wynosił 48 lat. Zdecydowana większość respondentów zamieszkuje miasta województwa świętokrzyskiego. Tylko trzech respondentów to mieszkańcy wsi. Z dokonanej analizy stażu 
pracy urzędników wynika, że każdy z nich przepracował średnio 26 lat. Wszyscy badani mają wyższe wykształcenie. Na stanowiskach kierowniczych w departamentach Urzędu Marszałkowskiego województwa świętokrzyskiego przeważają mężczyźni.

Pierwsze pytanie, które zadano respondentom, dotyczyło znajomości pojęcia ekonomia współdzielenia. Tylko pięciu badanych zadeklarowało, że spotkało się z tym terminem, jednak definicja tego pojęcia jest im nieznana. Pozostali respondenci nigdy wcześniej nie spotkali się z pojęciem ekonomia współdzielenia. Warto w tym miejscu wspomnieć, że po przedstawieniu przez autora definicji ekonomii współdzielenia zdecydowana większość badanych potrafiła podać konkretne przykłady firm i usług bazujących na założeniach sharing economy wyjaśniając, że samo pojęcie jest nieznane, ale idea tak.

Respondenci zostali zapytani o to, które miasta województwa świętokrzyskiego wyróżniają się otwartością na ekonomię współdzielenia. Badani wskazali na sześć miast: Starachowice, Kielce, Busko-Zdrój, Staszów, Ostrowiec Świętokrzyski i Skarżysko-Kamienna. Zdaniem urzędników są to miasta, które wyróżniają się na tle innych miast województwa świętokrzyskiego. Miasta te posiadają plan ogólnego rozwoju, prowadzą działania mające na celu poprawę warunków życia. W tych miastach można wykorzystać przede wszystkim narzędzia ekonomii współdzielenia w zakresie turystyki i transportu.

Urzędnicy podkreślają, że możliwości rozwoju ekonomii współdzielenia w miastach województwa świętokrzyskiego są duże, jednak najpierw musi się zmienić mentalność mieszkańców i władz samorządowych. „Największą szansę na wprowadzenie ekonomii współdzielenia w miastach naszego województwa mają systemy rowerów miejskich. Myślę, że z czasem pojawią się również inne formy, ale potrzeba na to trochę czasu" (Dyrektor Departamentu Promocji, Edukacji, Kultury, Sportu i Turystyki). „Wprowadzenie narzędzi ekonomii współdzielenia musi iść za zmianą mentalności społeczeństwa. Jesteśmy województwem małym, przebijającym się, próbującym doścignąć większe aglomeracje. Takie wypożyczalnie rowerów miejskich moim zdaniem mogłyby się przyjąć w Sandomierzu, w miastach, gdzie mamy rozwiniętą turystykę - rowery mogą ułatwić przemierzanie dróg turystycznych" (Dyrektor Departamentu Organizacyjno-Administracyjnego). Odmiennego zdania był Dyrektor Wojewódzkiego Zarządu Transportu, który uważa, że „podejmowane przez władze samorządowe działania są zależne od finansów.

Gdyby narzędzia ekonomii współdzielenia były opłacalne to myślę, że zostałyby wprowadzone i przyjęłyby się w miastach województwa świętokrzyskiego. Póki co nie mamy środków by inwestować w nowe rozwiązania, które być może poprawiłyby jakość życia mieszkańców miast".

Rozwój ekonomii współdzielenia w miastach województwa świętokrzyskiego determinowany jest przez wiele czynników, które mogą ułatwić lub utrudnić jej rozwój - o te czynniki zostali zapytani badani (zob. tab. 1). Zdaniem respondentów mentalność mieszkańców oraz zaufanie społeczne są pierwszymi czynnikami, które mogą ułatwić rozwój ekonomii współdzielenia. „Musi zmienić się mentalność społeczeństwa, które nie przywiązuje aż takiej wagi do własności. Warunkiem niezbędnym do tego, żeby ekonomia współdzielenia w różnych dziedzinach zafunkcjonowała jest wyższy poziom zaufania społecznego. Przekłada się to na szeroko rozumiany kapitał społeczny, aktywność społeczną w różnych dziedzinach, wiąże się to z dostatkiem, poczuciem bezpieczeństwa, zaufaniem. Musimy zmienić myślenie na prospołeczne i być bardziej aktywni w swojej lokalnej społeczności" (Zastępca Dyrektora Departamentu Polityki Regionalnej).

Niewątpliwie ważnym czynnikiem, który może przyczynić się do rozwoju ekonomii współdzielenia w miastach województwa 
świętokrzyskiego, jest edukacja. Ważne, aby podejmować działania mające na celu uświadomienie i edukowanie nie tylko społeczeństwa, ale także władz samorządowych. Czynnikiem, który może ułatwić rozwój ekonomii współdzielenia to również dostępne środki finansowe, „które włodarze mogą pozyskać z Unii Europejskiej" (Dyrektor Departamentu Organizacyjno-Administracyjnego).

\section{Tabela 1. Czynniki ułatwiające i utrudniające rozwój ekonomii współdzielenia w miastach województwa świętokrzyskiego}

\begin{tabular}{|c|c|}
\hline Czynniki ułatwiające rozwój ekonomii współdzielenia & Czynniki utrudniające rozwój ekonomii współdzielenia \\
\hline $\begin{array}{l}\text { - } \text { mentalność mieszkańców } \\
\text { - zaufanie społeczne i dobrobyt } \\
\text { - otwartość i aktywność mieszkańców } \\
\text { - świadomość mieszkańców } \\
\text { - edukacja z zakresu ekonomii współdzielenia } \\
\text { - świadomość władz samorządowych } \\
\text { - strategie miast uwzględniające założenia ekonomii } \\
\text { współdzielenia } \\
\text { - wzajemne dbanie o dobro wspólne } \\
\text { - społeczeństwo w wieku produkcyjnym } \\
\text { - dostępne środki finansowe } \\
\text { - specjalizacja miasta, np. turystyka } \\
\text { - współpraca międzyludzka } \\
\text { - chęć wspólnego użytkowania } \\
\text { - tworzenie wspólnoty współpracy } \\
\text { - otwartość na drugiego człowieka } \\
\text { - budowanie poczucia odpowiedzialności }\end{array}$ & $\begin{array}{l}\text { - brak zaufania społecznego } \\
\text { - brak środków finansowych } \\
\text { - mentalność społeczeństwa } \\
\text { - ubóstwo ekonomiczne } \\
\text { - brak myślenia prospołecznego } \\
\text { - starzejące się społeczeństwo } \\
\text { - stereotypy } \\
\text { - nierówności w społeczeństwie } \\
\text { - brak edukacji z zakresu ekonomii współdzielenia } \\
\text { - brak edukacji z zakresu wykorzystania nowych technologii } \\
\text { - brak społeczeństwa obywatelskiego } \\
\text { - niewykwalifikowani politycy } \\
\text { - brak zaangażowania mieszkańców } \\
\text { - brak wzajemnego szacunku } \\
\text { - brak wzajemnego dbania o dobro wspólne } \\
\text { - emigracja młodych ludzi } \\
\text { - brak zrozumienia } \\
\text { - brak zaufania do nowych form współpracy }\end{array}$ \\
\hline
\end{tabular}

Źródło: opracowanie własne na podstawie przeprowadzonych badań.

Do czynników, które mogą utrudnić rozwój ekonomii współdzielenia w województwie świętokrzyskim urzędnicy zaliczyli brak zaufania społecznego, które w przypadku ekonomii współdzielenia ma ogromne znaczenie, "chociaż młoda generacja mieszkańców zmienia proporcje i zwiększa zaufanie społeczne" (Dyrektor Departamentu Promocji, Edukacji, Kultury, Sportu i Turystyki). Czynnikiem utrudniającym rozwój ekonomii współdzielenia może być fakt, że „obserwujemy odpływ młodych ludzi, szczególnie z Kielc. Generalnie jest on duży i to nie sprzyja, bo społeczeństwo się starzeje. Mało jest miejsc dla seniorów, w których mogliby liczyć na informację, które by ich edukowały o możliwościach wykorzystania nowych technologii. Brak jest miejsc, które byłyby pozytywnie postrzegane. Następnie wskazać trzeba na niski status materialny i brak odpowiedzialność za cudzą rzecz" (Dyrektor Departamentu Wdrażania Funduszy Społecznych).

Respondenci zostali zapytani również o szanse i zagrożenia, jakie mogą wynikać z realizacji założeń ekonomii współdzielenia w miastach województwa świętokrzyskiego (zob. tab. 2). Do najczęściej wymienianych szans należy zaliczyć przede wszystkim tańsze podróżowanie, oszczędności, mobilność mieszkańców oraz dostęp do zwiększonej ilości dóbr i usług.

Ekonomia współdzielenia stwarza nie tylko szanse, ale i zagrożenia. Zdaniem badanych największym zagrożeniem są przepisy prawne i kwestie związane z podatkiem CIT, PIT oraz VAT. Z prawnego punktu widzenia należałoby określić, kim są podmioty, które uczestniczą w wymianie gospodarczej bazującej na 
założeniach ekonomii współdzielenia, jakie mają prawa i obowiązki. Dodatkowo według respondentów zagrożone mogą być przepisy dotyczące ochrony konsumentów (prosumentów) i ochrony danych osobowych. Zdaniem Dyrektora Departamentu Wdrażania Europejskiego Funduszu Regionalnego zagrożeniem może być również „zachowanie mieszkańców, mowa tu o dewastacjach mienia publicznego nie moje, to zniszczę, ale widzę więcej plusów, niż minusów. Ekonomia współdzielenia przyczynia się do budowania wspólnoty lokalnej i myślę, że będzie bardziej nastawione społeczeństwo na dbanie o nasze wspólne dobro, a nie tylko czyjeś".

\section{Tabela 2. Szanse i zagrożenia wynikające z realizacji założeń ekonomii współdzielenia}

\begin{tabular}{|l|l|}
\hline \multicolumn{1}{|c|}{ Szanse } & \multicolumn{1}{c|}{ Zagrożenia } \\
\hline - zwiększenie oszczędności & - niekorzystne przepisy prawne \\
- tańsze podróżowanie & - kwestie podatkowe \\
- lepszy komfort życia & - ochrona konsumentów \\
- budowanie lokalnej wspólnoty & - niska jakość usługi \\
- dążenie do zdrowej konsumpcji & - brak gwarancji otrzymania zamawianych dóbr lub usług \\
- podniesienie atrakcyjności miast & - problemy z ewentualnym dochodzeniem roszczeń \\
- wzajemne usługi edukacyjne & - brak odpowiedzialności \\
- lepsza mobilność mieszkańców & - dewastacje mienia publicznego \\
- zwiększona ochrona środowiska & \\
- dostęp do większej ilości dóbri i usług & \\
- maksymalne wykorzystanie zasobów poprzez efektywne & \\
- wspólne użytkowanie & \\
- otwarta wiedza oraz edukacja & \\
- zażliwości podróżowania osób mniej zamożnych & \\
- lepsze poznawanie odwiedzanych miejsc & \\
- zwiększenie liczby miejsc pracy & \\
\hline
\end{tabular}

Źródło: opracowanie własne na podstawie przeprowadzonych badań.

Badanie kończyło pytanie o perspektywy rozwoju ekonomii współdzielenia w miastach województwa świętokrzyskiego. Zdaniem respondentów ekonomia współdzielenia w sposób naturalny będzie się rozwijać: „Ważne jest, aby społeczeństwo miało pozytywne nastawienie do nowych projektów. Wszystkie narzędzia mogą wpłynąć pozytywnie na rozwój miast województwa świętokrzyskiego. Jestem optymistycznie nastawiony do ekonomii współdzielenia" (Dyrektor Wojewódzkiego Zarządu Transportu). Niewątpliwie bardzo ważną rolę będzie odgrywać edukacja: „Najpierw należy wyedukować społeczeństwo, później można wprowadzać np. wypożyczalnie rowerów, samochodów. Można wprowadzać powoli takie narzędzia, dzięki którym ludzie zobaczą, że mogą przyczynić się do chociażby ochrony środowiska i jednocześnie mogą $w$ ten sposób wiele zaoszczędzić" (Zastępca Dyrektora Departamentu Ochrony Zdrowia). Dyrektor Departamentu Wdrażania Europejskiego Funduszu Regionalnego również jest optymistycznie nastawiona do przyszłości ekonomii współdzielenia w miastach województwa świętokrzyskiego: „Mam nadzieję, że znane narzędzia zostaną wykorzystane i przyczynią się do poprawy jakości życia mieszkańców miast. Odbiór młodych ludzi jest bardzo pozytywny w zakresie wykorzystywania tych narzędzi, więc myślę, że włodarze będą wprowadzać te rozwiązania do strategii rozwoju miast" 
(Dyrektor Departamentu Wdrażania Europejskiego Funduszu Regionalnego).

Sharing economy to ciągle kształtujące się zjawisko. Trudno jednoznacznie określić jej przyszłość. Niewątpliwie zachodzące zmiany społeczno-gospodarcze i rozwój technologii będą miały duży wpływ na jej dalszy rozwój. Nie ma pewności co do optymistycznych wizji respondentów dotyczących przyszłości ekonomii współdzielenia w województwie świętokrzyskim. Jedno natomiast jest pewne - dotychczasowy styl życia mieszkańców miast musi ulec zmianie. Badania wskazują, że współczesny tryb życia mieszkańców miast (szczególnie metropolii) bezpośrednio zagraża Ziemi. Należy poszukiwać rozwiązań, które w znacznym stopniu mogłyby ograniczyć eksploatację środowiska naturalnego i ekosystemu. Jednym z takich rozwiązań może być właśnie ekonomia współdzielenia.

\subsection{Ekonomia współdzielenia w opinii przedsiębiorców województwa świętokrzyskiego}

Celem prowadzonych badań była diagnoza obecnego stanu wiedzy przedsiębiorców woje- wództwa świętokrzyskiego w zakresie ekonomii współdzielenia z uwzględnieniem kontekstu problematyki miejskiej. Badania ilościowe przeprowadzono za pomocą kwestionariusza ankiety na próbie liczącej 45 przedsiębiorców zrzeszonych w Świętokrzyskim Związku Pracodawców Prywatnych „Lewiatan”, posiadających siedzibę swojej firmy na terenie województwa świętokrzyskiego. Bania realizowane były od sierpnia do końca grudnia 2017 r. Kwestionariusz ankiety składał się z szesnastu pytań zamkniętych oraz jednego nieobowiązkowego pytania otwartego. Badania prowadzone były on-line oraz w oparciu o indywidualny kontakt badacza z respondentem podczas odbywającego się szkolenia dla przedsiębiorców.

W badanej populacji nieznacznie przeważali mężczyźni, którzy stanowili 53,3\% wszystkich respondentów. Najliczniejszą grupę stanowili przedsiębiorcy w przedziale wiekowym od 46 do 55 lat. Większość przedsiębiorców $(82,2 \%)$ w swoich firmach zatrudnia do dziesięciu pracowników. Blisko 30\% firm reprezentowanych przez przedsiębiorców funkcjonuje na rynku powyżej 20 lat (zob. tab. 3).

\section{Tabela 3. Charakterystyka przedsiębiorstw reprezentowanych przez respondentów}

\begin{tabular}{|l|c|c|}
\hline & Częstość & Procent \\
\hline Liczba pracowników zatrudnionych w przedsiębiorstwie & 45 & 100,00 \\
\hline do 10 osób & 37 & 82,2 \\
10-49 osób & 6 & 13,3 \\
50-250 osób & 2 & 4,4 \\
\hline Liczba lat funkcjonowania przedsiębiorstwa na rynku & 45 & 100,00 \\
\hline do 1 roku & 3 & 6,7 \\
1-5 lat & 10 & 22,2 \\
6-10 lat & 5 & 11,1 \\
11-15 lat & 7 & 15,6 \\
16-20 lat & 8 & 17,8 \\
powyżej 20 lat & 12 & 26,6 \\
\hline
\end{tabular}

Źródło: opracowanie własne na podstawie przeprowadzonych badań.

Biorąc pod uwagę zasięg działalności przedsiębiorstw reprezentowanych przez badanych respondentów, dominowały te, które działają na rynku międzynarodowym
- stanowiły one 33,3\% całej populacji badawczej. Najczęściej przedsiębiorstwa prowadzą działalność w branży usługowej $(53,3 \%)$ oraz handlowej $(26,7 \%)$. 
Ekonomia współdzielenia jest pojęciem rozpoznawalnym wśród przedsiębiorców województwa świętokrzyskiego. Blisko $60 \%$ badanych deklaruje, że zetknęło się z nim.
Ekonomia współdzielenia jest zatem bardziej rozpoznawalna wśród przedsiębiorców niż wśród urzędników województwa świętokrzyskiego.

\section{Tabela 4. Rozkład odpowiedzi na pytanie: Czy korzystał/a lub słyszał/a Pan/Pani o poszczególnych usługach bazujących na założeniach ekonomii współdzielenia?}

\begin{tabular}{|l|c|c|c|c|c|c|c|c|}
\hline & \multicolumn{2}{|c|}{$\begin{array}{c}\text { Tak słyszałem/am } \\
\text { i korzystałem/am }\end{array}$} & $\begin{array}{c}\text { Tak słyszałem/am, } \\
\text { ale nie korzysta- } \\
\text { łem/am }\end{array}$ & $\begin{array}{c}\text { Nie słyszałem/am, } \\
\text { ale korzystałem/am } \\
\text { (nieświadomie) }\end{array}$ & $\begin{array}{c}\text { Nie słyszałem/am } \\
\text { inie korzystałem/ } \\
\text { am }\end{array}$ \\
\cline { 2 - 11 } & częstość & udział & częstość & udział & częstość & udział & częstość & udział \\
\hline $\begin{array}{l}\text { Współużytkowanie samochodów (np. } \\
\text { car-sharing: Autolib, Car2Go, Zipcar, } \\
\text { Uber) }\end{array}$ & 5 & 11,1 & 31 & 68,9 & 2 & 4,4 & 7 & 15,6 \\
\hline $\begin{array}{l}\text { Współużytkowanie rowerów miejskich } \\
\text { (np. Veturillo, Nextbike) }\end{array}$ & 5 & 11,1 & 34 & 75,6 & 1 & 2,2 & 5 & 11,1 \\
\hline $\begin{array}{l}\text { Współużytkowanie skuterów elektrycz- } \\
\text { nych (np. Blinkee) }\end{array}$ & 2 & 4,4 & 18 & 40,0 & 2 & 4,4 & 23 & 51,1 \\
\hline $\begin{array}{l}\text { Wspólne przejazdy prywatnym samo- } \\
\text { chodem między miastami (np. BlaBlaCar) }\end{array}$ & 13 & 28,9 & 29 & 64,4 & 1 & 2,2 & 2 & 4,4 \\
\hline $\begin{array}{l}\text { Usługa transportowa - przesyłka paczek } \\
\text { (np. jadezabiore.pl) }\end{array}$ & 5 & 11,1 & 18 & 40,0 & 0 & 0 & 22 & 48,9 \\
\hline $\begin{array}{l}\text { Udostępnianie mieszkania lub pokoju na } \\
\text { wynajem krótkoterminowy (np. Airbnb, } \\
\text { HomeAway) }\end{array}$ & 6 & 13,3 & 28 & 62,2 & 0 & 0 & 11 & 24,4 \\
\hline $\begin{array}{l}\text { Edukacja online, m.in. kursy, wykłady } \\
\text { online (np. Skillshare, Codecademy, Edx) }\end{array}$ & 10 & 22,2 & 25 & 55,6 & 0 & 0 & 10 & 22,2 \\
\hline $\begin{array}{l}\text { Świadczenie usług przez prywatne } \\
\text { osoby (np. TakeTask, Sir Local, SkillHunt, } \\
\text { TaskRabbit) }\end{array}$ & 16 & 35,6 & 0 & 0 & 4 & 8,9 & 25 & 55,6 \\
\hline $\begin{array}{l}\text { Powierzchnie coworkingowe - biura } \\
\text { do wspólnej pracy (np. Business Link, } \\
\text { MyMeetingRoom) }\end{array}$ & 21 & 46,7 & 0 & 0 & 2 & 4,4 & 22 & 48,9 \\
\hline $\begin{array}{l}\text { Współfinansowanie projektów oraz } \\
\text { pożyczki od osób prywatnych (PolakPo- } \\
\text { trafi.pl, Trejdoo.com, Kokos, Beesfund) }\end{array}$ & 5 & 11,1 & 18 & 40,0 & 1 & 2,2 & 21 & 46,7 \\
\hline $\begin{array}{l}\text { Sprzedaż produktów spożywczych } \\
\text { bez pośredników - bezpośrednio od } \\
\text { producenta (np. LokalnyRolnik.pl, } \\
\text { RanoZebrano.pl) }\end{array}$ & 3 & 6,7 & 32 & 71,1 & 0 & 0 & 10 & 22,2 \\
\hline
\end{tabular}

Źródło: opracowanie własne na podstawie przeprowadzonych badań

Do najbardziej znanych usług, z których korzystali respondenci, należą powierzchnie coworkingowe - biura do wspólnej pracy. Przedsiębiorcy słyszeli, ale nie korzystali z takich usług jak współużytkowanie samocho- dów (np. car-sharing Autolib, Car2Go), współużytkowanie rowerów miejskich (np. Veturillo, Nextbike) czy sprzedaż produktów spożywczych bez pośredników - bezpośrednio od producenta (np. LokalnyRolnik.pl, RanoZe- 
brano.pl). Do najmniej znanych usług bazujących na założeniach ekonomii współdzielenia należy zaliczyć współfinansowanie projektów, pożyczki od osób prywatnych (np. PolakPotrafi.pl) oraz współużytkowanie skuterów elektrycznych (np. Blinkee) (zob. tab. 4).

Respondenci zostali poproszeni o odniesienie się do siedmiu stwierdzeń (zob. tab. 5), które miały na celu zdiagnozowanie postaw sprzyjających bądź stanowiących barierę dla rozwoju ekonomii współdzielenia. Na podstawie uzyskanych wyników można przyjąć, że na ogół przedsiębiorcy mają postawy sprzyjające ekonomii współdzielenia. Dla 80\% respondentów dostęp do zasobów jest ważniejszych niż ich posiadanie, a $40 \%$ badanych jest w stanie obyć się bez większości rzeczy, które posiada. Zdecydowana większość przedsiębiorców zamiast wyrzucać rzeczy woli je oddać lub odsprzedać. Wyłania się nowy model ekonomiczny, który koncentruje się w mniejszym stopniu na posiadaniu oraz gromadzeniu, a w większym na społeczności i współpracy. Blisko 90\% respondentów zauważa, że we współczesnym świecie istnieje problem nadmiernej konsumpcji.

\section{Tabela 5. Rozkład odpowiedzi na pytanie: Czy zgadza się Pan/Pani z następującymi stwierdzeniami?}

\begin{tabular}{|l|c|c|c|c|c|}
\hline \multirow{2}{*}{ Stwierdzenia } & Zdecydowanie tak & Raczej tak & Raczej nie & Zdecydowanie nie \\
\cline { 2 - 5 } & \multicolumn{4}{|c|}{ w procentach } \\
\hline $\begin{array}{l}\text { Dostęp do rzeczy jest ważniejszy niż ich } \\
\text { posiadanie }\end{array}$ & 40,0 & 40,0 & 17,8 & 2,2 \\
\hline Pożyczanie jest tańsze niż kupowanie & 28,9 & 46,7 & 15,6 & 8,9 \\
\hline $\begin{array}{l}\text { Ograniczenie konsumpcji to zagrożenie dla miejsc } \\
\text { pracy }\end{array}$ & 15,6 & 46,7 & 28,9 & 8,9 \\
\hline $\begin{array}{l}\text { Mogę się obyć bez większości rzeczy, które } \\
\text { posiadam }\end{array}$ & 11,1 & 28,9 & 48,9 & 11,1 \\
\hline Zamiast wyrzucać, wolę oddać lub odsprzedać & 57,8 & 28,9 & 6,7 & 6,7 \\
\hline $\begin{array}{l}\text { Korzystam z serwisu wymiany lub mam zamiar } \\
\text { zacząćz niego korzystać w ciągu najblizszego roku }\end{array}$ & 11,1 & 31,1 & 55,6 & 2,2 \\
\hline $\begin{array}{l}\text { Obecnie występuje problem nadmiernej } \\
\text { konsumpcji }\end{array}$ & 48,9 & 37,8 & 13,3 & 0 \\
\hline
\end{tabular}

Źródło: opracowanie własne na podstawie przeprowadzonych badań.

Zaufanie jest jednym z newralgicznych czynników, które umożliwiają funkcjonowanie ekonomii współdzielenia, dlatego przedsiębiorcy zostali zapytani o skłonność do wypożyczania zasobów obcym osobom za pośrednictwem serwisów wymiany. Rozkład odpowiedzi badanych przedstawiono w tabeli 6. Respondenci najchętniej wypoży- czyliby za pośrednictwem serwisu wymiany rower lub inny sprzęt sportowy $(46,7 \%)$ oraz narzędzia ogrodnicze (42,2\%). Natomiast najrzadziej chcieliby wypożyczyć pokój w mieszkaniu (24,4\%), ubrania (24,4\%) oraz samochód (26,7\%). 20\% przedsiębiorców deklaruje, że nie wypożyczyłoby żadnej rzeczy. 
Tabela 6. Rozkład odpowiedzi na pytanie: Którą z następujących rzeczy wypożyczyłby Pan/ wypożyczyłaby Pani obcej osobie za pośrednictwem serwisu wymiany?

\begin{tabular}{|l|c|c|}
\hline \multicolumn{1}{|c|}{ Warianty odpowiedzi } & Częstość & Procent* \\
\hline Urządzenia elektroniczne & 15 & 33,3 \\
\hline Rower lub inny sprzęt sportowy & 21 & 46,7 \\
\hline Narzędzia ogrodnicze & 19 & 42,2 \\
\hline Ubrania & 11 & 24,4 \\
\hline Samochód & 12 & 26,7 \\
\hline Pokój w mieszkaniu & 11 & 24,4 \\
\hline Żadna z powyższych & 9 & 20,0 \\
\hline
\end{tabular}

* Odsetki nie sumują się do 100, ponieważ respondent mógł wybrać więcej niż jedną odpowiedź.

Źródło: opracowanie własne na podstawie przeprowadzonych badań

Tabela 7. Rozkład odpowiedzi na pytanie: Jak Pan/Pani ocenia warunki dla rozwoju ekonomii współdzielenia w miastach województwa świętokrzyskiego

\begin{tabular}{|l|c|c|}
\hline \multicolumn{1}{|c|}{ Warianty odpowiedzi } & Częstość & Procent \\
\hline Bardzo dobrze & 1 & 2,2 \\
\hline Dobrze & 10 & 22,2 \\
\hline Trudno powiedzieć & 22 & 48,9 \\
\hline Źle & 5 & 11,1 \\
\hline Bardzo źle & 7 & 15,6 \\
\hline
\end{tabular}

Źródło: opracowanie własne na podstawie przeprowadzonych badań.

Przedsiębiorcy zostali również poproszeni o dokonanie oceny warunków dla rozwoju ekonomii współdzielenia w miastach województwa świętokrzyskiego. Pozytywnie warunki dla rozwoju ekonomii współdzielenia ocenia $24,4 \%$ badanych (suma odpowiedzi bardzo dobrze i dobrze), z czego 22,2\% respondentów ocenia je tylko jako dobre. Blisko $30 \%$ przedsiębiorców negatywnie ocenia warunki dla rozwoju ekonomii współdzielenia, natomiast blisko połowa badanych miała trudność z dokonaniem oceny (zob. tab. 7).

\section{Podsumowanie}

Ekonomia współdzielenia odzwierciedla dążenie społeczeństwa do zrównoważonego rozwoju, który należy rozumieć jako harmonijne współistnienie gospodarki, społeczeństwa i środowiska. Jej celem jest poprawa jakości życia społeczeństwa konsumpcyjnego. Obecnie trudno dokładnie zdefiniować pojęcie ekonomii współdzielenia ze względu na wczesny etap jej rozwoju oraz brak wypracowanego aparatu badawczego.

Analiza wyników badań przeprowadzonych w województwie świętokrzyskim w zakresie ekonomii współdzielenia pozwala na sformułowanie wniosku, iż jest to zjawisko relatywnie słabo rozwinięte. Jednak badani urzędnicy i przedsiębiorcy dostrzegają potencjał miast województwa świętokrzyskiego. Ekonomia współdzielenia w znacznym stopniu może przyczynić się do rozwiązania problemów, z którymi zmagają się miasta województwa świętokrzyskiego m.in. degradacją środowiska (zanieczyszczenie powietrza) i problemami komunikacyjnymi. Percepcja ekonomii współdzielenia w sferze praktycznej jest powszechna wśród urzędników i przedsię- 
biorców województwa świętokrzyskiego, natomiast samo jej pojęcie jest słabo zakorzenione w świadomości urzędników. Zaufanie jest jednym z kluczowych czynników, które umożliwiają funkcjonowanie ekonomii współdzielenia. Niewątpliwie z rozwojem ekonomii współdzielenia wiążą się zarówno korzyści, jak i negatywne konsekwencje. Procesy legislacyjne zachodzące w odniesieniu do sharing economy będą mogły mieć ogromny wpływ na jej dalszy rozwój.

\section{Literatura}

Banaszek M. (2016). „Ekonomia współdzielenia jako alternatywny kierunek rozwoju miast", Ekonomia Społeczna, nr 1, Kraków: MSAP UEK.

Botsman R., Rogers R. (2010). What's Mine is Yours. The rise of collaborative consumption. New York: Harper Collins Publishers.

Dorda K. (2015). "Sharing city", Magazyn Miasta, nr 1(9).

Hamari J., Sjoklint M., Ukkonen A. (2015). "The Sharing Economy: Why People Participate in Collaborative Consumption", Journal of Association for Information Science and Technology, vol. 67, nr 9.

Maffesoli M. (2008). Czas plemion. Schyłek indywidualizmu w społeczeństwach ponowoczesnych. Warszawa: Wydawnictwo Naukowe PWN.

Petropoulos G. (2017). An Economic Review of the Collaborative Economy, http://bruegel.org/2017/02/ an-economic-review-of-the-collaborative-economy (data dostępu:01.06.2018).

Rifkin J. (2016). Spoleczeństwo zerowych kosztów krańcowych. Warszawa: Studio EMKA.

Sundararajan A. (2014), Peer-to-peer Businesses and the Sharing (Collaborative) Economy: Overview, Economic Effects and Regulatory Issue, http://smallbusiness.house.gov/uploadedfiles/1-15-2014 revised_sundararajan_testimony.pdf (data dostępu: 29.05.2018).

\section{Sharing economy in the opinion of officials and entrepreneurs of the Świętokrzyskie Province: Conclusions from empirical research}

Summary: Sharing economy is a socio-economic phenomenon consisting in the direct provision of services by people, co-creation and sharing of available resources. Its main purpose is to move from ownership to access. The purpose of the article is to present the phenomenon of sharing economy in the context of urban issues in the awareness of officials and entrepreneurs of the Świętokrzyskie Province. In the tests, which were both qualitative and quantitative, the method of diagnostic survey and two research techniques were used: in-depth interview technique and survey technique. The tools used to conduct the research are an interview questionnaire and a questionnaire. The sharing economy is a relatively low developed area in the Świętokrzyskie province. Confidence is one of the critical factors that enable the functioning of the sharing economy.

Keywords: sharing economy, social economy, development, city, consumption.

\section{Prawa autorskie i licencja / Copyright and License}

Artykuł opublikowano na licencji Creative Commons

Uznanie autorstwa - Użycie niekomercyjne - Bez utworów zależnych 3.0 Polska

http://creativecommons.org/licenses/by-nc-nd/3.0/pl/

This article is published under the terms of the Creative Commons

Attribution - NonCommercial - NoDerivs (CC BY-NCND 3.0) License

http://creativecommons.org/licenses/by-nc-nd/3.0/ 